\title{
THE PORTS OF THE MEDIEVAL ADRIATIC OPEN RESEARCH PROSPECTS
}

\section{FLOCEL SABATÉ}

Keynote lecture

DOI: 10.1484/J.HAM.5.111327
F. Sabaté

Universitat de Lleida

Plaça Victor Siurana, 1

25003 Lleida

Catalonia, Spain
The inherent dangers in the sea seem lesser than the difficulty of travelling overland in medieval Europe, with its seriously deficient roads, limitations in load bearing and severe jurisdictional fragmentation. ${ }^{.}$Supplying ships with victuals and water, repairing the vessels and moving produce had an evident effect on the port cities. Thus, as Jehel and Racinet stated, "dès le début du Moyen Âge, il existe une corrélation évidente entre le développement du commerce maritime et l'expansion urbaine". ${ }^{2}$ Seaports then played a role that is not always sufficiently recognised in the historiography and one that affected all aspects of human relations, whether economic, social or cultural.

If this maritime scenario is focussed on as sea as specific as the Adriatic, this interest becomes even greater. An extensive bibliography details a long diachronic path, on which the cities and peoples involved have changed, although these have always coincided with the apparent contradiction of concentrating intense human exchanges and a frontier of diversity.

The medieval Adriatic was an area of great intensity and plurality. Therefore, the only way to talk about it without falling back on stereotypes requires detailed research and attention to specific areas. The diversity of recent research in distinct lines facilitates a move away from commonplace views and opens new perspectives for reflection. At the outset, we should note the diachronic route, that has changed the actors but always maintained the Adriatic area as a powerful epicentre that impregnates all the population of the epoch whether prominent or apparently anonymous people. In reality, the proximity of such a closed sea combined very diverse regional situations, with varied rhythms and multiple connections. This is not only a sea with two shores, the western and the eastern, but also with two spaces, one northern and another southern, because, even at the times of greatest homogeneity under the Venetian dominance, independent relations continued between Albania and Apulia in the south. The medieval Adriatic favoured close human relations, with marked demographic, economic and cultural exchanges in very varied and sometimes even contradictory situations. It is necessary, therefore, to reflect on cultural diversity and ultimately otherness and, inextricably, on the frontier, taken in the sense as porosity that favours contact.

With the Adriatic as a place of contact and diversity, the function of the ports as transmitters of values that structured their own territorial surroundings and linked to distant interior areas must be valued. The importance of the various ports and the strong external relations conditioned the predominance finally achieved by Venice. All this required, in the end, the existence of the port as a physical space, so that it's very morphology reflected the inherent social, political, fiscal and economic realities.

All this converts the ports on the medieval Adriatic into the scenario for an exchange which was simultaneously economic, cultural and political, in other words, essentially human.

\section{THE PORTS IN THE DIACHRONIC POSITIONING OF THE ADRIATIC}

The various (up to six) partitions of the Roman Empire proposed in the $4^{\text {th }}$ century came up against a conflictive point about the fate of Illyricum, either whole or divided, until the Germanic invasions imposed stabilisation, facilitated by the disappearance of the Western Roman Empire, and that left Dalmatia definitively under the eastern Empire. ${ }^{3}$ The Justinian reorganisation in the $6^{\text {th }}$ century consolidated the Adriatic within the Byzantine order and confirmed Ravenna as the capital. Its optimum position and power placed it beside and above the political changes, and it remained the leading city of Late Antiquity, with a great international influence. ${ }^{4}$ The link with the Greek-Oriental area is perceived in different cultural aspects ${ }^{5}$ or in the large-scale import of marble, surely from Constantinople, ${ }^{6}$ because after all, Ravenna was then the great port of the Adriatic, with all that meant for

${ }^{1}$ J. BERNARD, Comercio y finanzas en la Edad Media, 900-1500 in C. M. Cipolla, Historia económica de Europa (1) La Edad Media, Barcelona, 1987, p. 295-311. ${ }^{2}$ G. JEHEL, P. RACINET, La ville médiévale. De l'Occident chrétien à l'Orient musulman Ve-XVe siècle, Paris, 1996, p. 223.

3 É. DEMOUGEOT, Le partage des provinces de l'Illyricum entre la 'pars Occidentis' et la 'pars Orientis', de la tétrachie au règne de Théodoric in La géographie administrative et politique d'Alexandre à Mahomet, Leiden, 1981, p. 209-253.

${ }^{4}$ E. CIRELLI, Ravenna, archeologia di una città, Firenze, 2008.

${ }^{5}$ E. GRITTI, Ravenna tardoantica: il Liber pontificalis ecclesiae ravennatis e le recenti scoperte archeologiche in Medioevo Adriatico (MA) 4, Rome, 2012, p. 53-96.

${ }^{6}$ Y. A. MARANO, Il commercio del marmo nell'Adriatico tardoantico (IV-VI secolo d.C.) in S. Collodo, G. L. Fontana (dirs.) Eredita culturali dell'Adriatico Archeologia, storia, lingua e letteratura, Rome, 2008, p. 159-174. 
the traffic of men, merchandise and ideas. ${ }^{7}$ Consequently, in Lopez-Jantzen's words, between the $6^{\text {th }}$ and $7^{\text {th }}$ centuries, "Ravenna remained wealthy in comparison with other centers both in Byzantine and Lombard north Italy as a result of its privileged political and economical position in the empire".

The area around the great capital could not fail to benefit from this dynamic. A little further north, Comacchio, which archaeologists have promoted in recent years, participated in the favourable conjuncture exploiting its excellent position to become "un emporio sul delta del Po", in the Early Middle Ages, with a great capacity to handle merchandise and protect shipping as a nodal axis between the Adriatic, Ravenna, the Po and with it, the Padanese cities.9

However, Ravenna had the excellent port of Classe, which acted as a link between the hinterland, beyond the Po Valley, and the Mediterranean linked permanently with the coasts of the Near East and the north of Africa. ${ }^{10}$ The vigour of this port marked the great difference with the possibilities of other coastal cities that were also strong at that time, like Rimini. In any case, the dynamism of Ravenna had a regional effect, and favoured a wider area made up not only of Rimini, but also Faenza, Forli or Cesena. In contrast, further south, outside this radius of influence, in the Marches the urban system of that same time fell into a full crisis, including the disappearance of places of reference. ${ }^{12}$

The remoteness and restructuring of the Byzantine area in the $9^{\text {th }}$ and $10^{\text {th }}$ centuries in reality had positive effects on the development of the ports on the Adriatic. The remoteness of Byzantium favoured the development of Venice, in an optimum position between Veneto and Istria. ${ }^{13}$ The international Byzantine context and the commercial incentive encouraged the development of the ports on the coast of Abruzzo and Molise. From the end of the $10^{\text {th }}$ century, great Benedictine monasteries in the interior and with deeplyrooted agricultural traditions like Volturno, Montecassino or San Clemente a Casauria had extended their properties and investments, sometimes very evidently: Santa Maria de l'isola di Tremiti, for example, acquired property on both sides of the Adriatic. In this investment dynamic, there was a notable appetite for building and controlling ports, in protected sites, with good communications with the interior and in the hands of monasteries, bishops and lay lords. The examples were the bishop of Chieti and the monastery of San Giovanni in Venere in the port on the Pescara River. It was so profitable that there were numerous private initiatives: the Count of Teate, Trasmondo III allied himself with the monastery of Tremite to create a port at the mouth of the Tecchio River and to spill the teloneum on all merchandise. ${ }^{14}$

Meanwhile, the increase in the commercial reach of Venice in the $11^{\text {th }}$ and $12^{\text {th }}$ centuries led to the use of force against the Slav population on the eastern shore of the Adriatic. ${ }^{15} \mathrm{At}$ the same time, on the western shore, Ancona was becoming consolidated. It was related directly to Constantinople in both the $12^{\text {th }}$ and $13^{\text {th }}$ centuries and the subject of famous adagios: unus Petrus in Roma, una turris in Cremona, unus portus in Ancona" ${ }^{16}$ or, as was still recalled in an early $16^{\text {th }}$ century Spanish text, "es el mejor puerto de toda esta costa e por este suelen decir 'un Dios, una Roma, un puerto en Ancona". ${ }^{17}$ As the papacy's port on the Adriatic and with good connections to both Rome and Florence, from the $13^{\text {th }}$ century, it would accept agreements with Venice, thus certifying the latter's pre-eminence. ${ }^{18}$

The rising power of Venice in the $12^{\text {th }}$ century became imperial, to use Ernesto Sestan's phrase, after it had benefited from the assault of Constantinople in 1204. The economic, political and social vigour of $13^{\text {th }}$-century Venice ${ }^{19}$ turned it into a power that correctly calculated strategy it should follow: avoid taking over vast territorial extensions in Asia and the Balkans, which would have been costly to maintain, and focus on strengthening its position in key places, seeking recognition from the leading towns on the Adriatic, including Parenzo (Poreč), Ragusa (Dubrovnik) or Durazzo (Durrëssi), and establishing fronts against possible rivals like Ancona. Thus, with close links of one kind or another between Venice and places from Capodistria to Ragusa in the mid $14^{\text {th }}$ century, ${ }^{20}$ the Adriatic became the

\footnotetext{
${ }_{7}$ G. TABACCO, L'italie médievale, Chambéry, 2005, p. 55-62.

${ }^{8}$ N. LOPEZ-JANTZEN, Reconceptualizing Ravenna's economic importance in the eight century in MA, 3 (2010), p. 125.

9 S. GELICHI, ed. Comoacchio e il suo territorio tra la tarda antichità e l'alto medievo, Comacchio, 2007. A brief abstract: S. GELICHI, Las estructuras portuarias de Comacchio y los puertos altomedievales en Italia in A. Fábregas, Navegación y puertos en época medieval y moderna, Granada, 2012 , p. 15-28. ${ }^{10}$ E. CIRELLI, A. CANNAVICCI, A $6^{\text {th }}$ Century dump from classe (Ravenna) in N. Poulou-Papodimitriou, E. Nodarou, V. Kililoglou, Late Roman Coarse Wares, Cooking wares and Amphorae in the Mediterranean. Archaeology and archaeometry. The Mediterranean: a market without frontiers, Oxford, 2014, p. 963-974.

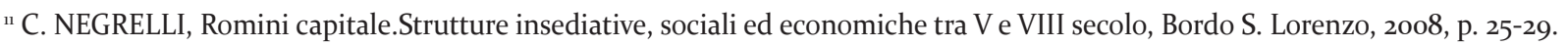

${ }^{12}$ E. CIRELLI, La ridefinizione degli spazi urbani nelle città dell'Adriatico centrale tra la tardo Antichità e l'alto Medioevo in, Hortus Artium Medievalium (HAM), 20/1, Zagreb-Motovun, 2014, p. 39-47.

${ }^{13}$ G. RAVEGNANI, Bisanzio e Venezia, Bologna, 2006.

${ }^{14}$ D. AQUILANO, Insediamenti, popolamento e comercio nel contesto costiero abruzzense e molisano (sec. XI-XIV). Il caso de Pennaluce in Mélanges de l'École Française de Rome, Moyen Âge, Temps Modernes, 109/1, Rome, 1997, p. 61-66.

${ }^{15}$ Probablement moins riches en butin, encore qu'il ne faille pas sous-estimer la valeur des esclaves qu'ils pouvaient en rapporter, les expéditions lancées par les Vénitiens contra les slaves diséminés sur la rive orientale de l'Adriatique n'en témoignent pas moins de la valeur militaire de leurs équipages et de leur aptitude à combattre sur terre comme sur mer, car, il n'est pas rare de voir les Vénitiens poursuivre loin à l'interieur des terres les barbades qui menacent la sécurité de leurs convois navals (J.-C. MAIRE VIGUEUR, Cavaliers et citoyens. Guerre, conflits et société dans l'Italie communale, XII siècles, Paris, 2003, p. 265).

${ }^{16}$ M. NATALUCCI, Ancona, Repubblica marinara, in Convegno di Studi Storici Federico Barbarossa, Ancona, e le Marche, Città di Castello, 1972, p. 28.

${ }^{17}$ A. RUCQUOI, De la séptima parte que es Italia in A. Guiance, P. Ubierna (dirs.), Sociedad y Memoria en la Edad Media. Estudios en homenaje de Nilda Guglielmi, Buenos Aires, 2005, p. 336.

${ }^{18}$ M. V. BIONDI, Ancona e il suo mare: norme, patti e usi di navigazione nei secoli XIV e XV, Recati, 1998.

${ }^{19}$ R. W. DORIN, Adriatic Trade Networks in the Twelfth and Early Thirteenth Centuries in C. Morrisson (dir.), Trade and Markets in Byzantium, Washington, 2012, p. 235-280.

${ }^{20}$ E. IVETIĆ, Le città dell'Istria (1260-1330), in G. Cherubini (dir.), Le città del Mediterraneo all'apogeo dello sviluppo medievale: aspetti economici e sociali. Diciottesimo conbegno Internazionale di Studi (Pistoia, 18-21 maggio 2001), Pistoia, 2003, p. 81-82.
} 
base that allowed Venetian power to be projected into the Aegean, ${ }^{21}$ and thus marking out a clear commercial power over the Eastern Mediterranean, ${ }^{22}$ with all its implications for political dominance. ${ }^{23}$

For this, Venice had had to overcome Angevin aspirations in the southern Adriatic. From the $13^{\text {th }}$ century, the presence of the Angevin dynasty in Naples marked the southern Italian coast. The physical and human proximity of Apulia and Albania in the early $14^{\text {th }}$ century converted the latter into an object of desire for Angevin Naples. In fact, at that time, armed companies like the Catalan were present in the Balkans, which led to the belief that a Latin domain would be created over the southern Adriatic and the Balkans. ${ }^{24}$

The failure of these aspirations in reality meant a new scenario for the differences between Venice and Anjou, given the latter's dynastic rights in Bohemia and Hungary. ${ }^{25}$ Louis the Great, King of Hungary and Croatia from 1342, grew stronger at the expense of Venice, which lost the ducal title exercised over Dalmatia and Croatia since the $11^{\text {th }}$ century in the Treaty of Zadar in $1358 .^{26}$ The new Hungarian influence over the Adriatic tried to combine the favour of the lesser nobility and the bourgeoisie. This is shown by the rise of cities like Zadar ${ }^{27}$ or the acceptation in Cattaro (Kotor), until then under Serbian dominance, and the lustre acquired by Ragusa from the $15^{\text {th }}$ century on was linked to this context.

Ladislaus of Naples and pretender of Hungary, who staged his intended Hungarian coronation in Zadar in 1403, ceded Dalmatia to Venice in 1409 in exchange for some money. Yet, the shadow of Hungary continued to loom: in 1480, Mathias Corbino attacked Bosnia, ravaging the countryside in Croatia. ${ }^{28}$ And notably, the pre-eminence of Venice in the Adriatic was visualised over the two shores perceived as being different. The above-mentioned Spanish description of the Adriatic in the $16^{\text {th }}$ century states that Venice was "señora de aquellos mares", but also indicated that Italy ended in "Aquileya que fue muy antigua e el puerto más nombrado que uvo en este mar Adriatico", ${ }^{29}$ thus perceiving Istria and Dalmatia as being different.

The chronological route has emphasised a permanent continuity based on the commercial potential and the inher- ent human exchange, although the protagonists changed. Throughout, it has highlighted the leading role of the coastal cities, with the power to form important regions, also linked to the interior. Therefore, a regional assessment of this space is necessary.

\section{UNITY AND REGIONALITY OF THE ADRIATIC}

A closed sea with shores close to each other like the Adriatic lends itself to exchanges. It could also be stated that mutual relations are so natural in this space that, rather than obeying economic speculation, they arise from balances between ecological shortfalls and surpluses, in the line of micro-ecology defined by Horden and Purcell..$^{30}$ However, different nuances immediately arise. In first place, demand: the transport of wine and oil from Istria to Ravenna in the $6^{\text {th }}$ century, for example, was due not to a shortage of these products on the Italian Peninsula but rather to urban needs. The demand was shaped by cultural habits: the importance of bread in the late medieval diet explains the high demand for grain in a city like Venice. The supply of Venice conditioned the treaties and strategies in the Adriatic in the $13^{\text {th }}$ century: thanks to its pre-eminence in Durazzo, grain, oil and wine were channelled from Albania to Venice, ${ }^{31}$ while, as well as food products, other urban requirements, like wool and cotton, were met from Apulia. The economic and social diversity, and the inclusion of various elements of ostentation in everyday life, extended all kinds of attractions in a city like Venice. In the $14^{\text {th }}$ century, good honey arrived from Romagna, ${ }^{32}$ and at the end of the medieval period, beeswax considered purer arrived from the Balkans and Romania. ${ }^{33}$

The consolidation of Venice as a great urbe could lead to a view of the Adriatic as a sea destined to meet its demands, in all its extension and conditioning the countryside of the various regions: most of the trade in a town like Camerino, in the interior of the Marches, was orientated towards Venice. ${ }^{34}$ This was why the ports were so important for channelling production from the interior, as Ancona was for the Apennine region throughout the Late Middle Ages, ${ }^{35}$ with a trade that went far beyond the wine that

\footnotetext{
${ }^{21}$ E. SESTAN, "La politica veneziana nel Duecento" in Archivio Storico Italiano, 135, Florence, 1977, p. $307-309$.

${ }^{22}$ E. CROUZET-PAVAN, Venice Triomphant. The horizon of a myth, Baltimore, 2002, p. 63-70.

${ }^{23}$ M. KNAPTON, Venice and the Terraferma, in A. Gamberini and I. Lazzarini, The Italian Renaissance State, Cambridge, 2012, p. 132-133.

${ }^{24}$ D. ABULAFIA, Il regno aragonese di Albania: un progetto angioino del 1311-1316 in Medioevo Saggi e Rassegne, 20, Cagliari, 1996, p. 13-23.

${ }^{25}$ G. M. CANTARELLA, L'ordine e il sole. Alle origini dell ‘Due Sicilie', in Svevi, angioini e aragonesi in Sicilia. Alle origine dell Due Sicilie, Udine, 2009 , p. 36-37.

${ }^{26} \mathrm{~N}$. BUDAK, M. JURKOVIĆ, Les Anjou et les territoires croates in F. Aceto, L'Europe des Anjou. Aventure des princes angevins du XII ${ }^{\mathrm{e}}$ au XVe siècle, Paris, 2001, p. 205-217.

${ }^{27}$ T. RAUKAR, Le città della Damazia nel XIII e XIV secolo in G. Cherubini (dir.), Le città del Mediterraneo all'apogeo dello sviluppo medievale: aspetti economici e sociali. Diciottesimo convegno Internazionale di Studi (Pistoia, 18-21 maggio 2001), Pistoia, 2003, p. 42-43.

${ }^{28}$ A. BÁRÁNY, Matthias's European Diplomacy in the 1480 os in A. Barány, A. Györkös (dir.), Matthias and his legacy. Cultural and Political Encounters between East and West, Debrecen, 2009, p. 371.

${ }^{29}$ A. RUCQUOI, De la séptima parte que es Italia in A. Guiance, P. Ubierna (dirs.), Sociedad y Memoria en la Edad Media. Estudios en homenaje de Nilda Guglielmi, Buenos Aires, 2005, p. 336.

${ }^{30}$ P. HORDEN, N. PURCELL, The Corrupting Sea. A Study of Mediterranean History, Oxford, 2000.

${ }^{31}$ A. DUCELLIER, La façade maritime de l'Albanie au Moyen Âge: Durazzo et Valona du XIe au XVe siècle Thessalonike, 1981, p. 62.

${ }^{32}$ A. CORTONESI, L'allevamento in Storia dell'Agricoltura Italiana, Florence, 2002, vol. II, p. 116.

${ }_{33} \mathrm{M}$. MORONI, Alcune note sulla produzione e sul commercio della cera in area adriatica tra basso mdioevo ed eta' moderna in 'Proposte e ricerche. Economia e societa nella storia dell'Italia centrale', 32, fasc. 62/1, Ancona, 2009, pp. 7-22.

34 E. DI STEFANO, Camerino nel Quattocento: dinamiche economiche, risvolti sociali e culturali con Venezia, 38, Ancona, 1997, p. 7-24.

${ }_{35}$ S. BORSARI, Merci importate ad Ancona dagli Appennini e attraverso gli Appennini nel basso medioevo, in Proposte e richerche. Economia e società nella storia dell'Italia centrale, 20, Ancona, 1988, p. 68-71.
} 
gave it fame,,$^{36}$ or Fano, among others, contributing grain from the Marches. ${ }^{37}$

The position of these port cities meant they were not only outlets for products but rather, in reality, it enabled each of them to consolidate its power and become the capital of a hinterland to supply and satisfy with the trade in products. This is clear in the case of Otranto, which even suffered tensions with Venice in the $12^{\text {th }}$ and $13^{\text {th }}$ centuries.

Therefore, this is not about a large centre that must be supplied, but rather a network of towns, in a hierarchical pyramid, so that each city was its own capital. This explains various degrees of regionality and the need for contacts in various directions. Throughout the Middle Ages, there were close relations between the ports on both sides of the sea, with Dalmatian products being transported to Ravenna, Ancona, Otranto or other ports, either to supply these cities or their regions of influence. So, for example, the demographic growth in both Terra de Bari and Terra de Otranto from the second half of the $15^{\text {th }}$ century explains the high demand for products, in many cases imported from the eastern shore through the ports of the regional capitals. ${ }^{38}$ In the same sense, the lasting importance of ports in the Marches like Fano, ${ }^{39}$ Pesaro and Ancona, should be understood as not only due to their own vitality but also to the dense internal network of cities they connected to. ${ }^{40}$ Moreover, demand for products from the other side of the Adriatic could also respond to more distant demands from neighbouring regions in the interior of the country. Examples of this would be the orders by Tuscan goldsmiths for lead and silver from Bosnia, which was loaded in Ragusa. ${ }^{41}$

Similarly, in the opposite sense, wine, grain or other products left the Italian coast for the east. An example is the wool from Apulia that was offloaded in Ragusa in the mid $15^{\text {th }}$ century..$^{42}$ The rise of Ragusa in the $12^{\text {th }}$ and $13^{\text {th }}$ centuries was based precisely on the establishment of up to 16 treaties with nearby cities on both sides of the Adriatic, as well as with the Despotate of Epirus. ${ }^{43}$ Maintaining these transversal contacts between the two shores meant human contact and exchanges reflected in all forms of expression, including artistic ones. ${ }^{44}$

Looking at the destinations of the ships that visited the medieval ports of Abruzzo and Molise, as Davide Aquilano has, shows a wide diversity: ships sailing to supply Venice, others linking the two sides of the Adriatic and also such neighbouring regions as the Marches to the north and Apulia to the south, while the archaeological research has shown the arrival of materials from eastern Padana and even coins from other political areas like Ancona and Ravenna. ${ }^{45}$ In a similar way, the Italian ports of Fermo and Termoli were permanently linked by sea. Thus, there was a constant, intense and varied relation of cabotage (or coastal shipping) between cities on the same side of the sea. This shows the vitality of these same cities, and is also coherent in the medieval reality: at that time, cabotage was usual along other Italian coasts ${ }^{46}$ in the rest of the Mediterranean ${ }^{47}$ or distant places like the Atlantic, ${ }^{48}$ and in fact, this in itself attracted investment by businessmen. ${ }^{49}$

The regional sense facilitated certain specialisations of ports: the high textile production from the interior of the Marches $^{50}$ left through the port of Fano mainly to Venice, while loads from Ancona more habitually were for the east and Catalonia, ${ }^{51}$ which tallies with the strong relation with Catalan wool, especially in the $15^{\text {th }}$ century..$^{52}$

In practice, the routes and distances were often intermingled: ships plying long-range routes called in to ports in the Adriatic, sometimes to take on supplies of fresh food

\footnotetext{
${ }^{3^{6}}$ A. RUCQUOI, De la séptima parte que es Italia in A. Guiance, P. Ubierna (dirs.), Sociedad y Memoria en la Edad Media. Estudios en homenaje de Nilda Guglielmi, Buenos Aires, 2005, p. 337.

37 V. BONAZZOLI, Il comercio del grano a Fano nel primo Quattrocento: la Compagnia Bettini-Malatesta in Proposte e ricerche. Economia e società nella storia dell'Italia centrale, 13, Ancona, 1984, p. 34-43.

${ }^{38}$ R. LICINIO, S. RUSSO, Mezzogiorno adriático in A. Cortonesi, M. Montanari (dirs.) Medievistica italiana e storia agraria, Bologna, 2001, p. 66.

39 G. SPALLACI, Il porto di Fano (PU) tra Tardoantichità e Medioevo: analisis storico-archeologica per una possibile ricostruzione topografica in Bizantinistica, 12, Spoleto, 2012, p. 149-184.

${ }^{40}$ G. PINTO, Le città umbro-marchigiane, in G. Cherubini (dir.), Le città del Mediterraneo all'apogeo dello sviluppo medievale: aspetti economici e sociali. Diciottesimo convegno Internazionale di Studi (Pistoia, 18-21 maggio 2001), Pistoia, 2003, p. 247-248.

${ }^{41}$ P. PIERUCCI, Il commercio dell'argento tra Ragusa e l'Italia centrale nel XV secolo, 52, Ancona, 2004, p. 28-48.

${ }^{42}$ M. SPREMIĆ, 1971, ДуБровник и арагонци, Belgrade, 1971, p. 210.

${ }^{43}$ P. F. PALUMBO, La Repubblica di Ragusa nelle relazioni fra le due sponde del'Adriatico in L'Abruzzo e la Repubblica di Ragusa tra il XIII e il XIV secoli. Atti del Convegno di Studi Storici (Ortona, 25-26 luglio 1987), Ortona, 1988, vol. I, p. 16-20.

${ }^{44}$ I. MATEJČIĆ, Il crocifisso rinascimentale della basilica Eufrasiana di Paranzo e altri esempi di manufatti lignei tra le due sponde dell Adriatico in E. Francescutti (dir.) Crocifissi lignei a Venezia e nei territori della Serenissima 1350 - 150o. Modelli - difuzione - restauro, Atti del convegno internazionale, Venezia, Gallerie dell'Accademia 18. maggio 2010, Padua, 2013, p. 133-144.

${ }^{45}$ D. AQUILANO, Insediamenti, popolamento e comercio nel contesto costiero abruzzense e molisano (sec. XI-XIV) in Mélanges de l'École Française de Rome, Moyen Âge, Temps Modernes, 109/1, Rome, 1997, p. 59-130.

${ }^{46}$ G. CHERUBINI, Impianto urbano e strutture architettoniche delle città portuali dell'Italia tirrenica, in B. Saitta (dir.), Città e vita cittadina nei paesi dell'area mediterranea. Secoli XI-XV. Atti in onore di Salvatore Tramontana (Adrano-bronte-Catania-Palermo, 18-22 novembre 2003), Rome, p. 100-103.

${ }_{47}$ C. GUILLERÉ, De Torroella de Montgrí a Tossa: les Catalans et la mer (fin XIII ${ }^{-}$-XIVe siècles) in Quaderns de la Selva, 13, Santa Coloma de Farners, 2001, p. $83-87$.

${ }^{48}$ J.-P. LEGUAY, Un aspecte de l'histoire et de l'économie urbaines bretonnes: les petits ports des aberts et des rias au XVe siècle in C. Connochie-Bourgne, (dir.), Mondes marins du Moyen Âge, Paris, 2006, p. 311-312.

49 S. BERNATO, "Le attività di Coluccio d'afflitto a Sorrento (1437-1439)", Schola Salernitatana. Annali, 11, Salerno, 2006, p. 336.

$5^{50}$ E. Di STEFANO, Il carteggio di un mercante cametie con Francesco di Marc Datini, 1395-1410, in Proposte e ricerche. Economia e società nella storia dell'Italia cetnrale, 37, Ancona, 1996, p. 194-221.

${ }^{51}$ N. LIPPARONI, Produzione e commercio della carta nel XV secolo. I libri dei "chamborieri” fabrianesi, in Proposte e ricerche, 13, Ancona, 1993, p. 25. ${ }^{52}$ E. ASHTOR Il commercio anconetano con il Mediterraneo occidentale nel basso Medioevo in Atti e Memorie della Deputazione di storia patria per le Marche, 87, Ancona, 1982, p. 25.
} 
and drinking water, and took advantage of these stops to exchange products, thus mixing products from long distance trade with others of a regional origin on the same ship.

The intensity of relations in different directions relates, in all cases, to the importance of urban society. This was the commercial stimulus favoured the development of the towns on the eastern shore of the Adriatic. They did not arise through trade, but adapted to it. As Tomislav Raukar states, "in the Balkans' highlands a town was first of all the castle or 'castrum' and afterwards a commercial purchase”. The feudal power of lords like the princes of Krk also favoured urban development and so laws favourable for this, like the "consuetudo" of Vinodol, were passed, just when various places, like Senj, were undergoing notable urban growth. ${ }^{53}$ Thus, with councils from the $12^{\text {th }}$ century and the rise of true bourgeois elites, ${ }^{54}$ the cities on the Dalmatian shore, smaller than their counterparts on the other side, grew around their respective ports, taking advantage of their optimum position, between West and East. 55

The predominance of Venice was based on the economic homogenisation and the respect for local entities within a size that was manageable. This can be seen in Istria, whose proximity converted it into a market and even a natural space for Venice, because the manoeuvres to enter and leave the port of Venice took ships towards Istria. Furthermore, many of the pilots lived in Istria, in places like Rovigno (Rovinj) and Parenzo (Poreč)..$^{56}$ At the same time, Istria underwent a notable urban development between the end of the $12^{\text {th }}$ century and the mid $13^{\text {th }}$, although this was polycentric and a fragmentation was maintained that was comfortable for Venice. ${ }^{57}$

This way, the Adriatic wove a network that combined unity and regionality at various levels, some of which were also international. The wool that reached Ragusa from both Apulia and Catalonia (both ruled by the same sovereign after 1442) was processed in the Dalmatian city,,$^{58}$ from where the textiles penetrated Bosnia and Serbia. ${ }^{59}$ At the same time, some Catalan merchants, like Joan de Roda, who sold the wool in Ragusa, were paid with Venetian bills of exchange. ${ }^{60}$

This mixture of scenarios implies that the movements in the Adriatic could not be separated from the situation inside it or the external political and economic setting.

\section{THE INTERNAL AND EXTERNAL POLITICAL CONTEXT}

One way or another, the economic and social vigour of the port cities affected, articulated and conditioned the respective regions, with all their institutional derivations. From this same incidence, the political, internal and external context appears therefore inextricably linked to the evolution of the respective ports and their fit in the territory.

This same attraction of the port cities could encourage external appetites that provoked apparent territorial dysfunctions. This was the case of Termoli at the end of the $10^{\text {th }}$ century. It had an important "portus" and presided over a county well integrated into the Principality of Capua and Benevento. ${ }^{61}$ However, due to its attraction, it was removed from its own administrative territory and came under Byzantine control until the arrival of the Normans a century later. Given its vigour, Termoli was able to establish its own policies. An example is the agreement of fraternity and friendship reached with Ragusa in $1203 .{ }^{62}$

In other cases, the organisation of the power structures in the territory directly affected the model of port. Thus, the new cities that grew up on the Abruzzo coast in the $13^{\text {th }}$ century, like Pennaluce or Francovilla, corresponded to the contemporary economic vigour, although this novelty was itself intertwined with the strengthening of the mechanisms used by Emperor Frederick II in the Kingdom of Sicily to regulate and control the tax system, including a new port where the tax on the circulation of goods was properly applied. This was the main reason why Pennaluce grew and why control was tightened over Pescara and Termoli. ${ }^{63}$

The political and diplomatic evolution could also affect places directly: in the $12^{\text {th }}$ century, the acquisitions and investments of Venice on the Adriatic coast that depended on the Norman kingdom of Sicily benefited these territories. In contrast, in the second half of the $13^{\text {th }}$ century, when serious differences arose between Venice and the Sicilian Anjous, the Adriatic ports entered into a crisis. The drop in income affected the finances of a kingdom that was simultaneously collapsing from strong internal tensions. The dynamic linked with the realignment of the port system in the $14^{\text {th }}$ and $15^{\text {th }}$ centuries in Abruzzo and Molise, which led to the disappearance of the ports of Pennaluce (in Vasco), Pescara, San Flaviano (in Ascoli) and Carrano, with only Termoli

53 T. RAUKAR, Rural and urban communities on the East Adriatic coast in the Middle Ages, in E. Benito, M. Espadas (dir.), $17^{\circ}$ Congreso Internacional de Ciencias Históricas, Madrid, 1992, vol. I, p. 106-108.

${ }^{54}$ N. BUDAK, Elites cittadine in Dalmazia nel tre- e quattrocento in M. P. Ghezzo (dir.) Città e sistema adriatico allafine del medioevo. Bilancio degli studi e prospettive di ricerca, Venice, 1997, p. 183-199.

55 T. RAUKAR, Le città della Damazia nel XIII e XIV secolo in G. Cherubini (dir.), Le città del Mediterraneo all'apogeo dello sviluppo medievale: aspetti economici e sociali. Diciottesimo conbegno Internazionale di Studi (Pistoia, 18-21 maggio 2001), Pistoia, 2003, p. 19-35.

${ }^{56}$ M. BERTOŠA, I porti istriani e i rifornimenti di cereali a Venezia nell'anno 1528 in Atti del Centro di ricerche storiche, 17, Rovinj, 1986-1987, p. 161.

${ }_{57}$ E. IVETIĆ, Le città dell'Istria (1260-1330), in G. Cherubini (dir.), Le città del Mediterraneo all'apogeo dello sviluppo medievale: aspetti economici e sociali. Diciottesimo convegno Internazionale di Studi (Pistoia, 18-21 maggio 2001), Pistoia, 2003, p. 82-93.

${ }_{5}^{8}$ C. CARRÈRE, La draperia en Catalogne et en Aragon au XVe siècle in Produzione, commercio et consumo di panni di lana nei secoli XII-XVIII. Atti delle Seconda Settimana di Studio dell'Istituto Internazionale di Storia Economica 'Francesco Datini' di Prato, Florence, 1976, pp. 475-559.

59 J. TADIĆ, Priveda Dubrovnika i srpske zemlje u provoj polovini XV veka in Zbornik Filozofskog Fakulteta, 10/1, Belgrade, 1968 , p. 519-536.

${ }^{60}$ N. FEJIĆ, Les catalans à Dubrovnik et dans le bassin Adriatique à la fin du Moyen Âge in Anuario de Estudios Medievales, 24, Barcelona, 1994, p. 431-432.

${ }^{61}$ L. FELLER, Pouvoir et société dans les Abruzzes autour de l'an mil : aristocratie, incastellamento, appropriation des justices (960-1035) in Bulletino dell'Istituto storico italiano, 94, Rome, 1988, p. 36-41.

${ }_{62}^{6}$ P. F. PALUMBO, La Repubblica di Ragusa nelle relazioni fra le due sponde del'Adriatico in L’Abruzzo e la Repubblica di Ragusa tra il XIII e il XIV secoli. Atti del Convegno di Studi Storici (Ortona, 25-26 luglio 1987), Ortona, 1988, vol. I, p. 16-20.

${ }^{63}$ D. AQUILANO, Insediamenti, popolamento e comercio nel contesto costiero abruzzense e molisano (sec. XI-XIV). Il caso de Pennaluce in Mélanges de l'École Française de Rome, Moyen Âge, Temps Modernes, 109/1, Rome, 1997, p. 86-102 
surviving. ${ }^{64}$ In short, this concatenation shows the relation between the international context, regional relations and the evolution of the local situation.

In the mid $15^{\text {th }}$ century, wool production increased in southern Italy with political incentives, "per effetto delle politiche proto-mercantiliste dei sovrani aragonesi", ${ }_{5}$ while economically distinct territories were becoming linked under the sovereignty of the Crown of Aragon: merino sheep from Valencia had even become acclimatised, and very high production was achieved. Between the 1440 and 50s, wool was exported from Apulia to Ragusa, where it coincided with wool from Catalonia, ${ }^{66}$ showing the power of the Catalan textile trade and its commercial companies and their coeval interest in the Aegean and north-eastern Mediterranean. ${ }^{67}$ However, the outbreak of the civil war in Catalonia in 1462 cut this flow and even placed Ragusa in danger, which solved this by intensifying imports of wool from Abruzzo, thus re-orientating a market that was, to a great extent, lost by the Catalans. ${ }^{68}$

This dependence on numerous and varied external factors shows the importance of having power of political and diplomatic negotiation for the rulers of the respective cities and towns. David Abulafia underlined that the success of Ragusa, as well as an ease for establishing good trade relations with Slavs, Bulgars and the "Romania", highlights the room for manoeuvre of the ruling elite, which was able to establish good relations and even recognise, according to the needs of the moment, Greco-Byzantine, Norman or Venetian sovereignty, and in all cases maintaining an autonomy such as when Ragusa accepted the pre-eminence of Venice from $1205^{69}$ and even its later formal links with Hungarians and, finally, with the Ottomans.

The importance of the relation with other governments and other populations shows that the port cities of the Adriatic stand out, to a great extent, as a meeting point with otherness.

\section{OTHERNESS AND IDEAS IN CONTACT}

The port cities that, many on the Adriatic, simultaneously acted as centres for business encouraged not only mobility but also the migration and settlement of people of very varied social levels. In the $14^{\text {th }}$ century, Ragusa was host to representatives of the great Tuscan families, who used it as a base for their business in Dalmatia, the Balkans and even Apulia. ${ }^{70}$ Economic development also attracted very diverse immigrants from the same Tuscany and many other places to the Dalmatian cities, attracted by the wide diversity of work..$^{71}$ The places trade relations were maintained with supplied a large number of immigrants, although these were distant lands. Thus, when there were close links between Catalonia and Ragusa in the second half of the $15^{\text {th }}$ century, many Catalans settled in the latter city. They did so either to set up trading companies or to work in manufacturing or tertiary activities, often related to the trading activities of their compatriots, like working with textiles (given the importance of wool imports) or in liberal professions as notaries, surgeons or teachers. A city like Ragusa offered a clearly pluralistic image, because "ces Vénitiens, Génois, Toscans et catalans, ces voyageurs originaires de tous les pays d'Europe" not only worked and traded in Ragusa but also settled, married, had families and even died there, which implied a natural and spontaneous mixture of ideas, cultures and traditions but also pressures for the economic prosperity achieved to be socially recognised and to derive into political access..$^{72}$

An important part of the urban immigration on the eastern shore of the Adriatic came from the Italian side, which contributed to a certain homogenisation of the maritime space. ${ }^{73}$ The notarial function contributed strongly to this: from the end of the $13^{\text {th }}$ century, in prominent cities like Ragusa, notaries from Italy had settled and developed their model of annotation and register. ${ }^{74}$

Venice, as a great late-medieval urban centre, based itself on its demographic attraction, which enabled of the city and its activities to continue to grow. As Mueller indicates, "de l'autre rive de l'Adriatique arrivèrent en outre à Venise de véritables masses humaines, homes et femmes, qui s'engagèrent comme galériens, marins ou domestiques".75 This flow had an economic value, but was also social and of identity, because it contributed to uniting the eastern Adriatic around Venice: the powerful Venetian fleet was in fact nourished by human resources from the eastern Adriatic: Dalmatians, Albanians and Greeks. ${ }^{7}$

A city with ostensible prosperity like Venice received immigrants on all levels of the social scale and from many different countries. The search for cultural affinities by newcomers affected the urban morphology, giving rise to a

\footnotetext{
${ }^{64}$ Ibidem

${ }^{65}$ R. LICINIO, S. RUSSO, Mezzogiorno adriatico in A. Cortonesi, M. Montanari (dirs.) Medievistica italiana e storia agraria Bologna, 2001, p. 64.

${ }^{66}$ N. FEJIĆ, Les catalans à Dubrovnik et dans le bassin Adriatique à la fin du Moyen Âge in Anuario de Estudios Medievales, 24, Barcelona, 1994 , p. 431-432.

${ }^{67}$ A. RIERA, G. FELIU, Activitats econòmiques in J. Sobrequès (dir.), Història de Barcelona, Barcelona, 1992, vol. III, p. 210.211.

${ }^{68}$ M. SPREMIĆ, 1971, ДуФровник и арагоніи, Belgrade, 1971, р. 210.

${ }^{69}$ D. ABULAFIA, Dalmatian Ragusa and the Norman Kingdom of Sicily in The Slavonic and East European Review, 54, London, 1976, p. 412-428.

$7^{70}$ F. BETTARINI, I toscani al servizio della città di Ragusa (Dubrovnik) nella prima metà del Quattocento in MA 1, Rome, 2007, p. 135-150.

${ }^{71}$ M. POPOVIĆ, La penetrazione dei mercanti Pratesi a Dubrovnik (Ragusa) nella prima metà del XV secolo in Archivio Storico Italiano, 177, Florence, 1959, p. 503-521.

${ }^{72} \mathrm{~N}$. FEJIĆ, Les étrangers à Dubrovnik (Raguse) au moyen âge: conflits et adaptation in V. Han, La culture urbaine des Balkans (XVe-XIXe siècles) (Belgrade, 2008), pp. 1721.

73 T. RAUKAR, Le città della Damazia nel XIII e XIV secolo in G. Cherubini (dir.), Le città del Mediterraneo all'apogeo dello sviluppo medievale: aspetti economici e sociali. Diciottesimo convegno Internazionale di Studi (Pistoia, 18-21 maggio 2001), Pistoia, 2003, p. 19-39.

${ }^{74}$ F. BETTARINI, L'Adriatico come punto di incontro tra differenti culture giuridiche: il caso dei notai della cancelleria ragusea in età umanistica in MA, 2 Roma, 2008, p. 35-54.

${ }^{75}$ R. C. MUELLER, 'Veneti facti privilegio : les étrangers naturalisés à Venise entre XIVe et XVIe siècle in J. Bottin, D. Calabi, Les étrangers dans la ville, Paris, 1999, p. 177.

${ }^{76}$ B. DOUMERC, Cosmopolitanism on Board Venetian Ships (Fourteenth-Fifteenth Centuries) in Medieval Encounters, 13, Leiden, 2007, p. 78-95.
} 
"regroupement d'étrangers dans l'espace urbain: si les rues des Albais sont nombreuses à Venise, il en existe aussi des 'Furlani (Frioulans), des Grecs, dels Padouans, des Ragusains, des Esclavons, des Allemands, des Turcs, ainsi que du Volto Santo des Lucquois". 77

The levels of social mixing propitiated by the Adriatic port cities were thus much deeper than the simple movement of people forced by slavery or occasional contacts for work reasons, as in the case of merchants. The expression "crocevia culturale", that has been applied precisely to heavily trafficked regions with great social porosity, like Molise, ${ }^{78}$ acquired its full sense in the Adriatic mix, structured on various levels. Thus, the intellectual attraction of city like Venice should come as no surprise or that, Georgius Ghemistos Plethon, a key figure in the introduction of Platonism in Renaissance Italy, should have stayed briefly in Venice in 1442 after taking part in the council of Ferrara-Florence.79 On another more mundane level, in the $15^{\text {th }}$ century, the use of labour from the Balkans and Albania in the making of Murano glass contributed to a greater sensitivity towards Byzantine artistic and cultural models..$^{80}$

These exchange were not merely formal but also became incrusted into the essential everyday experience of the population. Thus, the direct link between Apulia and Albania facilitated not only commercial and political penetration but also cultural contact, reflected in art and popular worship. The hagiographic exchanges between Albania and Calabria show contacts at a popular level, ${ }^{81}$ also highlighted in the high penetration of Latin and Catholic fashions and customs into Albania, ${ }^{82}$ especially in the $14^{\text {th }}$ and $15^{\text {th }}$ centuries, as reflected by worship and artistic styles. ${ }^{83}$ The contacts were fully transversal in nature thanks to the relations propitiated by the Adriatic: the figurative culture in the sculpture in Istria in the $12^{\text {th }}$ century can be linked to central-Italian models and the role of Zara (Zadar) as the capital of Dalmatian coast in the $14^{\text {th }}$ century naturally encouraged these influences which were also facilitated by the mobility inherent in the mendicant orders. ${ }^{84}$

This situation imposes a specific outlook for correctly interpreting the social and cultural parameters, including artistic production that inexorably must reflect the context from which it derives. To deal with the iconography of the episcopal chair of $12^{\text {th }}$-century Bari, Rowan W. Dorin tried to settle the various interpretive discussions warning that, having been made in Bari, this work should be analysed not as an Italian piece but as the result of a port city open to the varied cultural influences in the Mediterranean of the time: "because too few scholars have tried to see it as a dialogue rather than as a unified statement, while others have forgotten that Bari was not merely an Italian city, but a Mediterranean port with pan-Mediterranean influences". 85

The plurality propitiated by the Adriatic continued to show up significant cultural differences. The Catalan merchants crossed the Mediterranean from the west without linguistic difficulties until they reached the ports on the eastern shore of the Adriatic, where, on contacting peoples far from the Latin matrix, they found they needed translation. Language was thus an indicator of otherness. ${ }^{86}$ In the $12^{\text {th }}$ century, Al Idrisi had defined the Adriatic as the land of the Venetians and the Slavs. ${ }^{87}$ Such a closed sea, narrow and in touch, differentiated the people on one shore from the other.

During the Early Middle Ages, a Dalmatia attractive for Byzantines, Venetians and Normans, as well as the Papacy, differentiated between the Romans or Latins on the coast and the various Slav nations in the interior, often identified as pagans. According to Byzantine sources, the Slavs had gradually penetrated into the Balkans and the Peloponnesus in the $7^{\text {th }}$ and $8^{\text {th }}$ centuries, very fragmented into tribes, clans and families. They were initially seen as a danger by the Byzantines, and in the $9^{\text {th }}$ century, two areas, clearly differentiated at the political and cultural level, could be defined: the Greek-Byzantine and the Slav-Bulgar. ${ }^{88}$ Various circles of identity were thus defining among the Slavs, especially between Croats, Serbs and Narentanians. The circumstances of the $9^{\text {th }}$ century, on the edges of the Carolingian, Byzantine and Avar societies, facilitated that between the Adriatic and the Sava, a singular Croat identity was perceived, ${ }^{89}$ and even institutionally one could talk of a "regnum croatorum". Significantly, the changes in the Croatian ruling elite at the start of the $11^{\text {th }}$ century coincided with an alteration of the

\footnotetext{
77 R. C. MUELLER, 'Veneti facti privilegio : les étrangers naturalisés à Venise entre XIVe et XVIe siècle in J. Bottin, D. Calabi, Les étrangers dans la ville, Paris, 1999, p. 177-178.

${ }^{78}$ F. GANGEMI, Il Molise romanico : identità e influsi di una crocevia culturale in <https://www.academia.edu/6830378/Il_Molise_romanico_ identit\%C3\%Ao_e_influssi_di_un_crocevia_culturale>

${ }^{79}$ I.-V. LEB, A Byzantine Humanist between Catholicism and Islamism: Georgius Ghemistos Plethon (ca. 1360-1452) in A. Dumitran, L. Mádly, A. Simon (dirs.) 'Extincta est lucerna orbis': John Hunyadi and his Time, Cluj-Napoca, 2009, p. 319.

${ }^{80}$ S. MORETTI, Une communauté étrangère dans la Venise des XV et XVe siècles: le cas des Albanais, in J. Bottin, D. Calabi, Les étrangers dans la ville, Paris, 1999, p. 183-193.

${ }^{81}$ M. BIDOTTI, Un santo tra Oriente e Occidente. Atanasio e gli Albanesi di Calabria in MA, 3, Rome, 2010, p. $29-60$.

${ }^{82}$ A. PEPE (dir.), Itinerari di arte e devozione fra Albania e Puglia, Bari, 2008.

${ }^{8}$ G. CAMPOBASSO, Testimonianze di culto iacopeo e cateriniano in Albania ad una poca nota direttrice di pellegrinaggio: la chiesa de Shën Barbullës (S. Barbara) a Pllanë, in Ad Limina, 3/3, Santiago de Compostela, 2012, p. 43-71.

${ }^{84}$ L. MOR, Per una geografia artistica della scultura lignea monumentale nell'Alto Adriatico: alcuni Crocifissi tardo-romanici tra l'Istria e l'isola di Sansego; .F. TONOLO, Liturgia in figura: le miniature dei Corali di San Francesco a Zara in F. Toniolo, G. Valenzano, Medioevo adriatico. Circilazione di modelli, opere, maestri, Rome, 2010, p. 87-102, 121.

${ }^{85}$ R. DORIN, The Mystery of the Marble Man and His Hat:A Reconsideration of the Bari Episcopal Throne, in Florilegium 25, Waterloo (Ontario), 2008, p. 52. ${ }^{86}$ C. CASTELLANOS, La lingua franca, una revolució lingüística medieval amb aportació catalana $<$ https://www.uab.cat/Document/439/403/castellanos_linguafranca2007.pdf>

${ }^{87}$ G. MION, La quarta sezione del quinto clima nella 'Geografia’ di Al-Idrīsī in A. Arioli (dir.), Miscellanea Arabiga 2010-2011, Rome, 2011, p. 200.

${ }^{88}$ M. MORFAKIDIS FILACTÓS, M. CASAS OLEA, Fuentes griegas sobre los eslavos. I Expansión y establecimiento de los eslavos en la Península Balcánica, Granada, 2009, p. 20-21.

${ }^{89}$ D. DZINO, Becoming slav, becoming croat. Identity trasnformations in Post-Roman and Early Medieval Dalmatia, Leiden, 2010, p. 175-218.
} 
epigraphic models. $9^{\circ}$ In any case, the Slav population was rural in nature, the coastal cities being perceived as Latin. ${ }^{91}$ The dynamism of the $13^{\text {th }}$ and $14^{\text {th }}$ centuries propitiated ethnic-cultural contacts in Dalmatia between the Slavic character of the Croats from the interior and the Romanic elements from the cities, affecting the language, traditions and institutions. In contrast, at the same time, Istria maintained a greater duality between the coast and the cities, with Romanic language and culture on one hand, and the interior agricultural lands with a predominantly Slav population on the other. There were necessarily numerous contacts between both, but without any real mixing, which is why the notaries, who knew both languages, became optimum interlocutors in the mutual relations..$^{22}$

Contact with the eastern shore of the Adriatic was envisaged, in reality, as a gateway to the Slavs in the interior. This was very clear with the traders who came from far, like the Catalans. They were in Ragusa to access the metals and products from the Slavic interior, and even to contact the Greek and Bulgarian markets, all of which meant a clear multiplier effect with respect to contacts, geographic knowledge and human relations. ${ }^{93}$ It was assumed that otherness began in the eastern Adriatic, as travellers like the pilgrims on their way to the Holy Land noted. After disembarking in the Adriatic ports, they found increasing difficulties to understand the languages, and the political and the social structures as they penetrated deeper into the Balkans. ${ }^{94}$

In any case, the image of otherness remained, embodied in the Slav condition. The Dominican theologian, John of Ragusa, who was very influential in the $15^{\text {th }}$ century, was known precisely as "John the Slav". One of his missions was to establish a bridge between West and East to achieve the "reductio Graecorum", in other words, to attract the Eastern Church, a target that he believed feasible after the Western Schism had been overcome and in the context of the growing defensive difficulties in Constantinople. ${ }^{95}$

The Greco-Byzantine orthodoxy and Patarine-Bosnian heresy complemented otherness, often self-interestedly. The Bosnians were identified with Patarine heresies. The polemist text attributed to Paul of Dalmatia, ${ }^{96}$ who lost his life in 1255 at the hands of heretics near Split, was addressed to them. The late-medieval notarial documentation reflects the equivalence between Bosnian and patarino, with the intention of reducing anyone who was not a true Christian to slavery. ${ }^{97}$

In the $9^{\text {th }}$ century, Bari stood out as an importer of Muslimorigin slaves. ${ }^{98}$ In contrast, from the $13^{\text {th }}$ century and especially in the $14^{\text {th }}$, the Oriental slave market was concentrated very prominently on the ports on the eastern coast of the Adriatic, like Cattaro (Kotor), Zara (Zadar) and Ragusa. ${ }^{99}$ The slave trade was the main attraction of this city for Catalan traders until the $15^{\text {th }}$ century, specifying that that this was about the acquisition, "de quondam servam et captivam nostram de natione patarinorum". Yet, the complaints from those affected could reach the courts, like in Ragusa in 1393 where some claimed that they had been baptised -"de intuitu misericordie sacre matris ecclesie habeatis misericordiam nostri quia nos sumus Cristiane baptizate et nate de Christiani"-against the opinion of the merchant, who insisted he had acquired them as patarinas -"ego ipsas emi tanquam patarinas et pro patarinis volo tractare"-, this case concluding with their freedom because "esse contrata catholica" ${ }^{100}$ From the beginning of the $14^{\text {th }}$ century, the destinations of the slaves, like Sicily and the Crown of Aragon, established ways to free orthodox Bosnian and especially Greek slaves, which involved conversion to Catholicism and compensation to the owners, ${ }^{101}$ but which did not prevent tensions, trials in civil and ecclesiastic courts and the adoption of municipal measures of control in Barcelona. ${ }^{102}$ In Ragusa, the great council totally banned the slave trade in 1416, which re-orientated the objectives of merchants like the Catalans. ${ }^{103}$

The Slav or Italian duality evidently had different political and international consequences. In 1444, in Valencia, some Catalan traders who were negotiating with Ragusa, although through the financial system of Venice, requested their merchandise to be treated as Slavic and not Italian as that would mean lower taxation. ${ }^{104}$

One way or another, otherness had become established in the relations and perceptions in a sea with such high and permanent contacts as the Adriatic. This requires a particu-

\footnotetext{
90 F. DE RUBEIS, Tra Dalmazia e Italia: continuità e fratture dnelle iscrizioni della prime eta carolongia in HAM, 8, Zagreb-Motovun, 2002, p. 247-253.

${ }^{91}$ N. BUDAK, Identities in early Medieval Dalmatia (Seventh-Eleventh centuries) in I. H. Garipzanov, P. J. Geary, P. Urbańczyk (eds.), Franks, Northmen, and Slavs. Identitesand State Formation in Early Medieval Europe, Turnhout, 2008, p. 223-241.

${ }_{92}^{2}$ E. IVETIĆ, Le città dell'Istria (1260-1330), in G. Cherubini (dir.), Le città del Mediterraneo all'apogeo dello sviluppo medievale: aspetti economici e sociali. Diciottesimo convegno Internazionale di Studi (Pistoia, 18-21 maggio 2001), Pistoia, 2003, p. 108-109.

${ }^{93}$ N. FEJIĆ, Les catalans à Dubrovnik et dans le bassin Adriatique à la fin du Moyen Âge in Anuario de Estudios Medievales, 24, Barcelona, 1994, pp. 429-449.

${ }^{94}$ N. FEJIĆ, Les Balkans aux yeux des voyageurs Occidentaux au Moyen Âge in Voyages et voyageurs au Moyen Âge, Paris, 1996, p. 288-289.

95 J. S. MADRIGAL, La eclesiología de Juan de Ragusa O. P. (1390/95-1443), Madrid, 1995.

${ }^{96}$ PAUL LE DALMATE, La dispute entre le chrétien romain et le patarin bosnien, F. Šanjek. ed, Zagreb, 2000.

${ }^{97}$ N. FEJIĆ, Notes sur la traite des esclaves de Bosnie à Barcelona au Moyen Age (D’après les documents des Archives de Protocoles) in Estudis Històrics i Documents dels Arxius de Protocols, 10, Barcelona, 1982, p. 119-120.

${ }^{98}$ V. D'ALESSANDRO, Servi e liberi, in Uomo e ambiente nel Mezzogiono normanno-scevo. Atti delle ottave giornate normanno-sveve (Bari, 20-23 ottobre 1987), Bari, 1989, p. 299.

${ }_{99}$ C. VERLINDEN, L'esclavage dans l'Europe médiévale, Gent, 1973, vol. II, p. 797.

${ }^{100}$ N. FEJIĆ, L'esclavage et le discours antiesclavagiste au Bas Moyen Âge: quelques exemples du monde méditerranéen in L. Abenon, D. Bégot, J.-P. Sainton (dirs.), Construire l'histoire antillaise (Paris, 2002), p. 483-484.

${ }^{101}$ H. SAKURAI, Tráfico humano hacia la España medieval. Manumisión y mecenazgo in M. T. Ferrer, J. Mutgé (dirs.), De l'esclavitud a la llibertat. Esclaus i lliberts a l'edat mitjana, Barcelona, 2000, p. 80-85.

${ }^{102}$ F. SABATÉ, Gli schiavi davanti alla giustizia nella Catalogna bassomedievale in Schiavitù e servaggio nell'economia europea secc. XI-XVIII, Florence, 2014, p. 395.

${ }^{103}$ N. FEJIĆ, Notes sur la traite des esclaves de Bosnie à Barcelona au Moyen Age (D’après les documents des Archives de Protocoles) in Estudis Històrics i Documents dels Arxius de Protocols, 10, Barcelona, 1982, p.115-116.

${ }^{104}$ N. FEJIĆ, Les catalans à Dubrovnik et dans le bassin Adriatique à la fin du Moyen Âge in Anuario de Estudios Medievales, 24, Barcelona, 1994, pp. 431-432.
} 
lar reflection about the relation between this space and the notion of frontier.

\section{FRONTIERS}

Pierre Toubert defined the frontier as a living membrane. ${ }^{105}$ This should to be the model of frontier for the Adriatic, given the porosity with which the mentioned otherness had been in touch in their shores. After the division of the Roman Empire, the Adriatic acted as an area of contact and exchange between Byzantine lands and the Western Mediterranean. ${ }^{106}$ It became a point of exchange for products from both sides of the Mediterranean over the following centuries and notwithstanding changes in frontiers, which gave it specific characteristics.

With the Adriatic Sea consolidated as an area of exchange and even contacts with otherness, it must be asked whether this scenario could be affected by the political structuring of the states during the Late Middle Ages. For one thing, Hungary expanded to the gates of Venice itself in 1357 , which turned Dalmatia into a political border (the setting for frontier policies). ${ }^{107}$ The return of Dalmatia to Venetian sovereignty in 1409 coincided with a high point in Venetian intervention in the Italian Peninsula. With its domain of Terra Ferma strengthened in the $14^{\text {th }}$ century, ${ }^{108}$ in the $15^{\text {th }}$ it penetrated the Po Valley as far as Bergamo, reaching south to Ravenna, ${ }^{109}$ a sum of territories united more by juxtaposition than assimilation. ${ }^{110}$ This overland expansion was accompanied by a political discourse, which presented the Venetians as restorers of old freedoms, but also converted Venice into a continental power, forcing it to participate in the Italian politics and the tensions this involved. ${ }^{\text {"I }}$ Curiously, the needed for mercenary troops led to various combinations: in the $14^{\text {th }}$ century, a large number of Hungarians were contracted by Florence and in this guise, ended up attacking the Venetians. ${ }^{112}$
In the $15^{\text {th }}$ century, Alfonso the Magnanimous, the king of the Crown of Aragon, arrived on this stage. ${ }^{113}$ He incorporated the model of a humanist and sovereign court, ${ }^{114}$ and after settling in Naples in 1442 , he paid much attention to the government of this kingdom, building the fiscal system that affected its Adriatic ports. ${ }^{115}$ From these southern bases, he participated fully in Italian politics ${ }^{116}$ and, after 1435, he claimed all the Angevin rights over the Neapolitan crown, and Jerusalem and Hungary for himself, and even used the royal titles over Croatia, Dalmatia, Bulgaria and Serbia. ${ }^{117}$ In 1438, he received a Hungarian legation and in 1444, the regent Janco Hunyadi, addressed him to propose him to head a monarchy defined as elective, to lead an army against the Turks. Although agreement was close and the Magnanimous even contacted the king of Bosnia and the despot Branković of Serbia directly, the accord was not reached, and Janco Hunyadi was heavily defeated by the Turks at the battle of Kosovo in $1448 .{ }^{118}$

In the mid $15^{\text {th }}$ century, the posture of the Hungarian regent against the Turks earned him eulogies from Silvio Piccolomini, the future Pope Pius II, who praised him as a defender of Christendom. ${ }^{119}$ However, everyone played the game without taking their eyes off Italy: Janco Hunyadi initially hoped to face the Turks by negotiating with Genoa, the Sforzas of Milan and the Medicis of Florence, so that the agreement against the Turks also meant a certain anti-Venetian alliance. This was the context of the 1451 treaty between Venice and the Ottoman Empire. Yet, the failure of this strategy led the Hungarian regent to request Venetian help in the form of a loan from the San Giorgio bank in 1456, which enabled him to face the Turks, again alone, although this time he defeated them and stopped them before Belgrade. ${ }^{120}$

The calls by all the popes in the mid $15^{\text {th }}$ century (Eugene IV, Nicholas V, Callistus III, Pius II) for a crusade against the Turkish advance were received favourably in the cities of the eastern Adriatic, like Ragusa, that feared for their survival. ${ }^{121}$

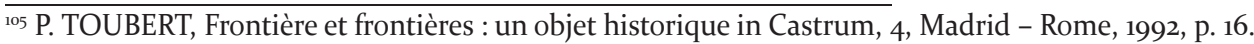

${ }^{106}$ N. DUVAL, L'Espagne, La Gaule et l'Adriatique. Rapports éventuels dans le domaine de l'Archéologie Chrétienne in Pere de Palol (dir) II Reunió d'Arqueologia Paleocristiana Hispánica (Montserrat, 2-5 de novembre de 1978), Barcelona, 1982, p. 50-51.

${ }^{107}$ S. MARIKO MILLER, Letters from the front(ier). Venetian rectors in Dalmatia, on the brink of war (1355) in MA, 1, Rome, 2007 , p. 7-30.

${ }^{108}$ F. PIGOZZO, Treviso e Venezia nel Trecento: La prima dominazione veneziana sulle podesterie minori (1339-1381), Venice, 2007.

${ }^{109}$ P. FORTINI BROWN, Arte y vida en la Venecia del Renacimiento, Tres Cantos, 1997, p. 12-13.

${ }^{10}$ M. KNAPTON, Venice and Terraferma in A. Gamberini, I. Lazzarini (dir.), The Italian Renaissance State, Cambridge, 2012, p. 132-155.

${ }^{\prime \prime}$ E. CROUZET-PAVAN, Renacimientos italianos (1380-1500), Valencia, 2007, p. 144-146.

${ }^{12}$ A. BARÁNY, The Communion of English and Hungarian Mercenaries in Italy in K. Papp, J. Barta, The first Millennnium of Hungary in Europe, Debrecen, 2002, p. 128-143.

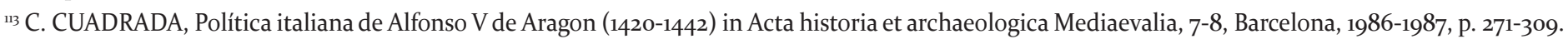

${ }^{114}$ E. DURAN, La imatge del rei Alfons in G. D'Agostino and G. Buffardi, XVI Congresso Internazionale di Storia della Corona d'Aragona.Celebrazioni Alfonsine, Naples, 2000, vol. II, p. 1405-1408.

${ }^{115}$ M. ALOISIO, Salt and royal finance in the kingdom and Naples under Alfonso the Magnanimous, in MA, 3 (2010), p. 9-28.

${ }^{116}$ A. RYDER, Alfonso el Magnánimo, rey de Aragón, Nápoles y Sicilia (1396-1458), Valencia, 1992, p. 221-376.

${ }^{17}$ A. De BERZEVICZY, Rapporti storici fra Napoli e l'Ungheria nell'epoca degli Aragonesi (1442-1501) in Atti dell'Accademia Pontiana, 58, Naples, 1928, p. 181-182.

${ }^{118}$ F. D. SOPORAN, Ethnic Attitudes in the kingdom of Hungary and the Defense of Christendom in the Mid 1400 in A. Dumitran, L. Mádly, A. Simon (dirs.), Extincta est lucerna orbis': John Hunyadi and his Time, Cluj-Napoca, 2009, p. 290-291.

${ }^{19}$ O. MURESAN, John Hunyadi -the Ideal Crusader- in Aeneas Silvio Piccolomini's. Letters and Historical Writings in A. Dumitran, L. Mádly, A. Simon (dirs.) 'Extincta est lucerna orbis': John Hunyadi and his Time, Cluj-Napoca, 2009, p. 35-41.

${ }^{120}$ A. SIMON, The Captain and the 'Superba'. Relations between John Hunyadi and Genoa (October 1444-September 1455) in A. Dumitran, L. Mádly, A. Simon (dirs.), Extincta est lucerna orbis': John Hunyadi and his Time Cluj-Napoca, 2009, p. 339-343.

${ }^{121}$ I. PRLENDER, An Eastern Adriatic Republic (Dubrovnik): Facing the Temptations of the Crusaders in Z. Hunyadi, J. Laszlovsky (dirs.), The Crusades and Milityary Orders. Expanding the Frontiers of Medieval Latin Christianity, Budapest, 2001, p. 173-186. 
Leading such an action seemed appropriate for Alfonso the Magnanimous, receptor of the messianic tradition from $13^{\text {th }}$ century Sicily that had taken root in the sovereigns of Crown of Aragon, ${ }^{122}$ who were the subjects of the prophecies that foretold him as destructor sarracenorum and the creator of a new order of a universal monarchy. ${ }^{123}$ The grandiloquence of this discourse, coherent with the directives that called for an urgent reform of the Church until the $15^{\text {th }}$ century ${ }^{124}$ and even the proximity of the end of time, when God waited for his united flock, ${ }^{125}$ did not tally with Alfonso's real power. Having been unable to seat himself on the Hungarian throne, Alfonso returned to the old Angevin aspirations to Albania, consistent with the close relations between the southern shores of the Adriatic. Two tears after a delegation was sent there in 1447, Aragonese troops arrived in Albania, initially to help Scanderberg against the Turks, and in 1451 Alfonso's viceroy for Albania, Sclavonia and Greece, settled in Croia (Krujë), then separated the latter country in 1455 with the appointment of a viceroy for Morea. ${ }^{126}$

Italian affairs undermined any joint action in the East. The aspirations of the Magnanimous to the Duchy of Milan in 1447 or the ongoing tensions between Venice and Naples, despite the peace treaty signed in 1450 , amplified the tensions. Thus, the Venetians were suspicious of all Alfonso's actions in the southern Adriatic, including his backing for Scanderberg, which they continuously tried to block. Identical discomfort was caused by the support the Magnanimous gave to the Grand Duke Vukčić of Bosnia in 1444, who controlled what corresponded roughly to modern Montenegro, and even more, the vassalage received in 1452, in Epirus, from the despot Leonard II Tocco of Artà who ruled over various Ionian islands and territories in the Despotates of Epirus and Achaia. ${ }^{127}$ It was precisely from Durazzo that Venice maintained its investments and supplies in Albania. ${ }^{128}$

However, the policy the Magnanimous intended to apply to the Adriatic and the Balkans was, in Momčilo Spremićs words, "un misto di idee dei crociati e di mire alla creazione di un impero mediterraneo". Faced with this objective, the reality was very different. As the same author stated, "aspirando a stabilirsi nei Balcani, Alfonso il Magnanimo ci incontrò un mondo diverso. Forse non lo conosceva abastanza. Comunque gli rimase estaneo e longano. La popolazione dei Balcani non capiva e non amava i nobili e frati catalani mandativi. Persino $i$ Turchi le erano più vicini e non di rado la gente si metteva dalla loro parte". ${ }^{129}$

In this context, some lords accepted a strong Neapolitan influence. These included the Toccos, who even modelled their administration on the institutional structures of the Crown of Aragon. ${ }^{130}$ However, the inability of the lords of the Balkans to act together and the permanent disputes between the Italian lords, contrasted with the constant Turkish advance. The latter, in any case, provoked important population movements from one side of the Adriatic to the other. In the second half of the $14^{\text {th }}$ century, a large number of Slavs and Albanians crossed the sea to try to settle in Italian cities. These were overwhelmed by this migratory flow and tried to prevent it. For example, the "consiglio de credenza" of Macerata emitted various decrees of expulsion, which were as ineffective as other measures, with the result that a new neighbourhood, the Borgo di San Giovanni, populated with immigrants sprang up. ${ }^{131}$ However, the strong diaspora had its own social scales, as in the great emigration that followed the loss of Scutari to the Turks: while many Albanians of lowly origin left for Venice, the aristocracy preferred to seek refuge in Naples. ${ }^{132}$

By the end of the $14^{\text {th }}$ century, the Turkish advance had led to an increase in the Venetian presence in the southern Adriatic, around Albania and Corfu. ${ }^{133}$ However, the following century would show the fragility of this area. In 1480, in the context of the siege of Rhodes, the Turks, annoyed at the support of the Neapolitan king for the knights Hospitallers, assaulted the port and city of Otranto. ${ }^{34}$ With the Adriatic thus converted into the frontier with the Turks, the ports adapted to the new scenario. Venice reconstructed its hinterland, especially in the central and northern Adriatic area, where it increased its influence and stabilised its economic, political and territorial relations not only with the ports but also throughout the region. Nevertheless, the economic and social reality adapted rapidly to the political changes. It was soon appreciated that the Turkish presence, in reality, opened new markets and renewed contacts: Ragusa experienced a period of great prosperity in the $16^{\text {th }}$ century. ${ }^{135}$

\footnotetext{
${ }_{122}$ M. AURELL, Eschatologie, spiritualité et politique dans la confédération catalano-aragonaise (1282-1412) in Fin du monde et signes des temps. Visionnaires et prophètes en France méridionale (fin XIII' ${ }^{\mathrm{e}}$-début XV ${ }^{\mathrm{e}}$ siècle), Toulouse, 1992, p. 191-235.

${ }^{123}$ D. BARCA, Alfonso il Magnanimo e la tradizione dell'imaginario profetico catalano in G. D’Agostino and G. Buffardi, XVI Congresso Internazionale di Storia della Corona d'Aragona. Celebrazioni Alfonsine, Naples, 2000, vol. II, p. 1283-1291.

${ }^{124}$ F. SABATÉ, Vivir y sentir en la Edad Media. El mundo visto con ojos medievales, Madrid, 2011, p. 87-91.

${ }^{125}$ R. MANSELLI, Età dello Spiritu e profetismo tra quattrocento e cinquecento in A. Crocco (dir.) L'Età dello Spiritu e la fine dei tempi in Gioacchino de Fiore e nel Giochimismo Medievali. Atti del II Congreso Internazionale di Studi giochimiti, San Giovanni in Fiori, 1986, p. $237-253$.

${ }^{126}$ M. SPREMIĆ, Alfonso il Magnanimo e la sua politica nei balcani in G. D’Agostino and G. Buffardi, XVI Congresso Internazionale di Storia della Corona d'Aragona.Celebrazioni Alfonsine, Naples, 200o, vol. I, p. 741-753.

${ }^{127}$ N. ZEČEVIĆ, Confirmation grant of king Alfonso V of Aragon to Leonardo III Tocco (july 16 1452): an authentic charter with a fake justification? in Collection of Papers. Philosophy, Mathematics and Natural science, 14/2, Pale, 2012, p. 9-19.

${ }^{128}$ A. KOLA, Aspects of the economic policies and commercial practices if the venetian administration in littoral albanian cities, 1392-1479 in MA, 4 (2012), p. 97-112.

${ }^{129}$ M. SPREMIĆ, Alfonso il Magnanimo e la sua politica nei Balcani in G. D’Agostino and G. Buffardi, XVI Congresso Internazionale di Storia della Corona d'Aragona.Celebrazioni Alfonsine, Naples, 2000, vol. I, p. 750.

${ }^{130}$ N. ZEČEVIĆ, The Tocco of the greek realm. Nobility, Power and Migration in Latin Greece $\left(14^{\text {th }}-15^{\text {th }}\right.$ centuries), Sarajevo, 2014, p. 129-13.0

${ }^{131}$ E. SARACCO, Convivere nella Marchia durante il medioevo. Indagini e spunti di ricerca, Ancona, 1986, p. 139-140.

${ }^{132}$ A. DUCELLIER, Les Albanais à Venise aux XIVee et XVe siècles in Travaux et mémoires du Centre de recherche d'histoire et civilisation byzantines, 2 , Paris, 1967, p. 420.

${ }^{133}$ M. KNAPTON, Venice and the Terraferma in A. Gamberini, I. Lazzarini (dirs.), The Italian Renaissance State, Cambridge, 2012, p. 133-135.

${ }^{134}$ J.-B. DE VAIVRE, "Autour du siège de 1480", in Société de l'histoire et du patrimoine de l'Ordre de Malte, 22, Paris, 2009, p. 36-117.

${ }^{135}$ Giulia SPALLACCI, Le relazioni economiche nell'Alto e Medio Adriatico tardo medieval attraverso lo studio dei trattati commerciali in < http://amsacta. unibo.it/3771/1/SPALLACCI.pdf>
} 


\section{THE PORT: MORPHOLOGY OF THE PHYSICAL SPACE}

A port did not necessarily mean the existence of a city around it. For example, Peníscola in the Kingdom of Valencia has been defined as the finest natural medieval port but was never more than a simple loading point, without the capacity to generate a minimally urban centre. ${ }^{136}$ However, an area like the Adriatic, based on communication between nuclei endowed with great vitality, can be defined as a network of port cities. Thus, each of them had a neuralgic point that was a tangible physical space: the port. Fernand Braudel wrote precisely that, "le vrai coeur de Venise n'est ni sur ses places ni sir l'arche du pont de Rialto, mais dans ce 'bacino di San Marco' qui est son port". ${ }^{137}$ Although this claim could be generalised, the case of Venice was somewhat different, because, in Jean Claude Hocquet's words, "le port était partout". ${ }^{138}$

Whatever the size of the port, they all required places for loading and unloading passengers and goods, with warehouses to store such products as grain, wool, wood, salt and fish. In this sense, the medieval Adriatic port could be compared with other Mediterranean or Atlantic ports. ${ }^{139}$ At the same time, the services required and the specialisation of trades in the Middle Ages meant a network of artisans (ropers, carpenters and many others), traders, sailors and ship-owners, who all together made up, everywhere, a truly varied micro-society in the port district.

Socially, the mixture became completely transversal: the loading and unloading of ships, with high manpower needs, was reserved for the lower layers of society. This was a tense area, with frequent judicial interventions for verbal and physical aggression and illegal gambling. This diversity of the social aspects and employment went beyond the strict port area, as it meant activities and negotiations in different settings in the city. First, we should mention the notaries, because they had to keep the notarial registers that held the agreements reached between companies, for contracts and finance. At the same time, the investing elite who ran the businesses also pressured the political management to be favourable to them, which facilitated the practical blurring of the limits between the public and the private.
Thus, one way or another, a large part of the city's population was involved in trade or the activities of the port. This was in addition to a large non-resident foreign population, who, in the best of cases, sought help from a consulate, either their own one or that of another close national group, which allowed them to receive support before the local authorities, arbitration in disputes and various services (notary, chapel, taverns, etc.) to attend to the sailors, as well as storage and protection for the merchandise. ${ }^{140}$

There were two outstanding elements in all Adriatic ports: the arsenal and the shipyard. ${ }^{141}$ Their role was vital for the survival and protection of a port society and combined with the need for defence in a busy city with high social mobility and their situation in a frontier context. In this scenario, Nenad Fejić's dual definition for Ragusa is apt: espace de convergence, espace menace. ${ }^{142}$

This became a central concern for the Adriatic ports, even those like Ragusa that enjoyed good natural protection. ${ }^{143}$ In 1353, Venice added a chain, like the one in Ragusa, for if it became necessary to block the port. Defensive castles at the entrance, or the lighthouse that lit the tower of Sant Nicolò from 1312, completed the initial defences in Venice. ${ }^{144}$ Starting with the militia that dated from the $12^{\text {th }}$ century, Ragusa entered into a defensive spiral during the Late Middle Ages, justified by the tensions with neighbouring powers but in reality, was part of the strategies of the ruling elite to control the population. This hastened the organisation of an urban militia, the deployment of guards at strategic points, like the entrance to the city, bridges and the arsenal, the recruitment of mercenaries and the building of a system of defence works, and the protection of the arsenal with the corresponding urban reforms. ${ }^{145}$

The external tensions, international complexity, commercial competitiveness, proven presence of spies serving foreign powers ${ }^{146}$ and other dangers encouraged local governments to introduce measures to protect the port together, on the other hand, with action to promote and facilitate the arrival of sailors and merchants. ${ }^{147}$ Moreover, in Venice, measures for isolation, with quarantine stations on islands, were introduced in the $14^{\text {th }}$ century to protect the popula-

\footnotetext{
${ }_{136}$ C. RABASSA, Funcions econòmiques del port de Peníscola durant la baixa edat mitjana in R. Narbona, XVIII Congrés Internacional d'Història de la Corona d'Aragó (Valencia, 2004), València, 2005, vol. II, p, 1269-1290.

${ }^{137}$ F. BRAUDEL, Venise in La Méditerranée. Les hommes et l'héritage, Paris, 1986, p. 168.

${ }^{138}$ J.C. HOCQUET, Le système portuaire de Venise à la fin du Moyen Âge in F. Fabre, D. Le Blévec, D. Menjot, Les ports et la navigation en Méditerranée au Moyen Âge. Actes du Collloque de Lattes (12, 13, 14 novembre 2014), Montpellier, 2009, p.125.

${ }^{139} \mathrm{~J}$.-P. LEGUAY, Un aspecte de l'histoire et de l'éconnomie urbaines bretonnes: les petits ports des aberts et des rias au XV siècle in C. Connochie-Bourgne, (dir.), Mondes marins du Moyen Âge, Paris, 2006, p. 307-314.

${ }^{140}$ M. T. FERRER i MALLOL, El consolat de mar i els consolats d'ultramar, instrument i manifestació d'expansió del comerç català in L'expansió catalana a la Mediterrània a la baixa edat mitjana, Barcelona, 1999, pp. 72-79.

${ }^{141}$ J. C. HOCQUET, Le système portuaire de Venise à la fin du Moyen Âge in F. Fabre, D. Le Blévec, D. Menjot, Les ports et la navigation en Méditerranée au Moyen Âge. Actes du Colloque de Lattes (12, 13, 14 novembre 2014), Montpellier, 2009, p. 129-142.

${ }^{142}$ N. FEJIĆ, Dubrovnik (Raguse) au Moyen-Age, espace de convergence, espace ménacé, Paris, 2010.

${ }^{143}$ N. FEJIĆ, Construire et controler: le gouvernement de Dubrovnik (Raguse) face au défi de la construction et de la protection des infrastructures portuaires (XIVe-XVe siècles), in P. Boucheron, E. Mornet (dirs.), Ports maritimes et ports fluviaux au Moyen Âge, Paris, 2005, .p. 117-118.

${ }^{144}$ J.C. HOCQUET, Le système portuaire de Venise à la fin du Moyen Âge in F. Fabre, D. Le Blévec, D. Menjot, Les ports et la navigation en Méditerranée au Moyen Âge. Actes du Collloque de Lattes (12, 13, 14 novembre 2014), Montpellier, 2009, p. 133.

${ }^{145}$ N. FEJIĆ, Defense politics in a Mediterranean city: Medieval military threats to Dubrovnik (Ragusa) and emergent tensions between defensive strategy and securing public order in Imago temporis Medium Aevum, 4, Lleida, 2010, p. 307-328.

${ }^{146}$ M. SPREMIĆ, Alfonso il Magnanimo e la sua politica nei balcani in iG. D’Agostino and G. Buffardi, XVI Congresso Internazionale di Storia della Corona d'Aragona.Celebrazioni Alfonsine, Naples, 200o, vol. I, p. 744.

${ }^{147}$ N. FEJIĆ, Construire et contrôler: le gouvernement de Dubrovnik (Raguse) face au défi de la construction et de la protection des infrastructures portuaires
} (XIVe-XVe siècles), in P. Boucheron, E. Mornet (dirs.), Ports maritimes et ports fluviaux au Moyen Âge, Paris, 2005, p. 121-122. 
tion from the dangers of epidemics, adopting not only these steps of separating the population but also precautions with merchandise, that could even be burned. ${ }^{148}$

By definition, the ports were the ways in and out of cities that relied on maritime power for their prosperity and development. This, the morphology of the physical space of the port became a portrait of the different aspects of all the society.

\section{OPEN REFLECTIONS}

The secular view shows the Adriatic as a sea characterised by intense economic and cultural exchanges, propitiated by some very dynamic port cities. Otherness became an enriching value, showing the importance of the permanent crossroads: between East and West, between Slavs and Latins and finally between Christianity and the Turkish contribution. A closed sea converted into a frontier of permanent contact.

Along the way, the interpretation has focussed on the cities. These were featured by their social complexity on one hand, and, on the other, by their external projection, which meant that they gradually became linked to each other in a network of concatenated capitals superimposed on each other. Thus, all the cities had both a region of influence and a pyramidal relation with other centres.

The late medieval pre-eminence of Venice must be interpreted within this setting. The city imposed its commercial power - "la présence vénitienne était massive dans toutes les places de commerce"149- and so one can say, like Elisabeth Crouzet-Pavan, that after its dominance in the $13^{\text {th }}$ and $14^{\text {th }}$ centuries, "vive un second apogée, quand Venise conquiert, dans les premières décennies du XVe siècle, un leadership qui n'est plus seulement italien mais véritablement européen". ${ }^{50}$ Braudel added an apparently poetic nuance, writing that Venice, "a été la reine de l'Adriatique, la souveraine de la Méditerranée". ${ }^{151}$ Rowan W. Dorin proposed the Adriatic as a Venetian contado. ${ }^{152}$ This is a very apt phrase given the political centrality achieved through the agreements Venice established with other cities, the economic pre-eminence in the supply, the demographic attraction to feed Venetian needs for manpower and the political role it played. However, this expression is especially valid in view of the influence each medieval city exerted over its surroundings, with which it established a specific region of influence, whose size was proportional to the power of the respective city. ${ }^{153}$
In this sense, from the $12^{\text {th }}$ century, the leading Venetian families had invested preferentially all down the Adriatic, so that the establishment of the elite's economic bases and the construction of a region of influence for Venice were two sides of the same coin. ${ }^{.54}$

Nevertheless, precisely given the same social, political and economic fabric based on this urban concatenation, the medieval Adriatic was much more than a Venetian contado. The pre-eminence of Venice did not extinguish other capitals, but simply it headed the urban pyramidal network. Each of the Adriatic port cities participated in a territorial network, exercising as its own capital and with the power to enter into relations. This view enriches the perspectives enormously and imposes greater complexity by mixing the various lines of relation between specific cities, not only with their immediate surroundings but also with both shores of the Adriatic, or the regions in the interior, with no need for a relation with Venice. This imposes a need to revise the interpretation, as Luca Palozzi did when he questioned whether it was correct to continue to use "scultura veneziana gotica" for an Adriatic production that, in reality combined various influences, and not precisely Venetian ones. ${ }^{55}$

Seeing the Adriatic as a crossroads is no rhetorical expression. Thus, understanding all its realities means being able to integrate a very open perspective, given the catalysing character of the port cities. The hinterland of each of these went far beyond their immediate surroundings, which facilitated important economic, social, cultural and artistic amalgams.

Thus, prudence is required to interpret the value of the historical data correctly. This prudence should extend to the heuristic sources, where chance has often played a role in their historical fate, which should be duly compensated for. Important notarial archives have totally or partially disappeared, so the real weight of ports like Ancona needs to be rebuilt despite these gaps in the documentation. The same happens with the archaeological sources. As Davide Aquilano warned, many affirmations about the difficulties of the ports in Abruzzo and Molise were really based on alterations of the territory in the $2 \mathrm{O}^{\text {th }}$ century and thus, a good interpretation required an effort to recover the correct reading of the historical landscape despite these later alterations. ${ }^{156}$

To sum up, given its physical and human characteristics, the medieval Adriatic basin became a special scenario of exchanges, and this same singularity imposes specific prudence

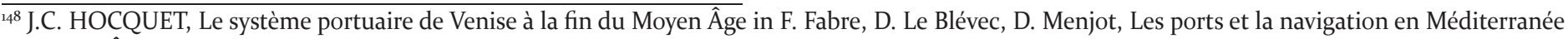
au Moyen Âge. Actes du Colloque de Lattes (12, 13, 14 novembre 2014), Montpellier, 2009, p.134-135.

${ }^{149}$ J. C. HOCQUET, Solidarités familiales et solidarités marchandes à Venise au XIVe siècle in Les élites urbanies au Moyen Âge. XXVII ${ }^{e}$ Congrès de la SHMES (Rome, mai 1996), Paris, 1997, p. 251.

${ }^{150}$ E. CROUZET-PAVAN, Venise et ses apogees: problèmes de definition in G. Cherubini (dir.), Le città del Mediterraneo all'apogeo dello sviluppo medievale: aspetti economici e sociali. Diciottesimo convegno Internazionale di Studi (Pistoia, 18-21 maggio 2001), Pistoia, 2003, p. 71.

${ }^{151}$ F. BRAUDEL, Venise in La Méditerranée. Les hommes et l'héritage, Paris, 1986, p. 177.

${ }^{152}$ R. W. DORIN, "Adriatic Trade Networks in the Twelfth and Early Thirteenth Centuries" in C. Morrisson (dir.) Trade and Markets in Byzantium, Washington, 2012, p. 241.

${ }^{153}$ F. SABATÉ, Renovación económica y social : el mundo urbano in V. A. Álvarez Palenzuela (dir.), Historia Universal de la Edad Media, Barcelona, 2002, p. 519-526.

${ }^{154}$ R. DORIN, Les activités économiques des familles vénitiennes dans l'Adriatique (XII et XIII'e siècles) in B. Caseau (dir.) Les réseaux familiaux: Antiquité tardive et Moyen Âge, Paris 2012, p. 325-333.

${ }^{155}$ L. PALOZZI, Venetian or Adriatic? Refocusing the Geography of Late Medieval Stone Sculpture in the Central Adriatic Basin: Four Case Studies in HAM, Zagreb-Motovun, 20, 2014, p. 862-873.

${ }^{156}$ D. AQUILANO, Importuosa litora in Considerazioni di storia ed archeologia, 7, Campobasso, 2014, p. 35-68.
} 
on the interpretation so as to capture its true diversity. The cultural legacy shows mutual collaboration and symbiosis of ideas, beyond the tensions that have always accompanied a frontier area. In the end, on the shores of the Adriatic, it is easy to understand Toniolo and Valenzano's words about culture, "unico strumento capace di aprire strade di dialogo differenti rispetto a quelle della supremazia del potere politico e della potenza distruttive degli esercitti." ${ }^{157}$

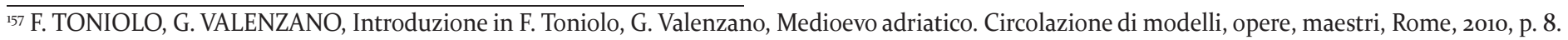

